Столярова А. В. Древнерусские надписи XI-XIV веков на пергаменных кодексах. М., 1998.

Столярова Л. В. Свод записей писџов, художников и переплетчиков древнерусских пергаменных кодексов XI-XIV веков. M., 2000.

Шапов Я. Н. Государство и џерковь Древней Руси Х-XIII вв. М., 1989.

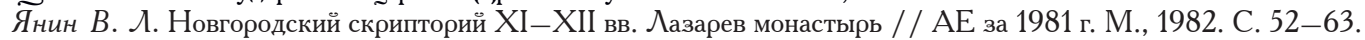

Янин В. А., Гайдуков П. Г. Актовые печати Древней Руси Х-XV вв. М., 1998. Т. 3: Печати, зарегистрированные в 1970-1996 гг.

Garland L. Anna Dalassena, Mother of Alexius I Comnenus (1081-1118) [Электронный pecypc]. URL: www.roman-emperors.org/ annadal.htm (дата обрашения: 20.12.2018).

Mitsiou E. Frauen als Gronderinnen von Doppelklusstern im Byzantinischen Reich / Wiener Jahrbuch fbr Kunstgeschichte. 2011/2012. Bd. LX/LXI. S. 333-343.

Yury A. Artamonov

The Institute of Russian History of the Russian Academy of Sciences, Institute of World History of the Russian Academy of Sciences, Moscow, Russia

\title{
“DOUBLE MONASTERIES” IN OLD RUS’
}

The analysis of annals and hagiography leads the author to the conclusion that there were “double monasteries" in Old Rus': houses in which communities of monks and nuns coexisted. Such houses included: the Monastery of St. Andrew in Kiev (the 1080s), the Dormition Monastery in Vladimir (the 1090s), the Transfiguration Monastery in Polotsk (the 1120s), the Monastery of St. Lazar in Novgorod (the late $11^{\text {th }}$ century). The author argues that one of the earliest "double monasteries" of Rus', the Monastery of St. Andrew in Kiev, followed the model of the Monastery of Christ Pantepoptes in Constantinople founded by Anna Dalassene, the mother of Byzantine emperor Alexios I Comnenos (1081-1118).

Keywords: “double monasteries", St. Andrew Monastery in Kiev, Dormition Monastery in Vladimir, Transfiguration Monastery in Polotsk, St. Lazar Monastery in Novgorod, Monastery of Christ Pantepoptes in Constantinople, Prince Vsevolod Yaroslavich of Kiev, Yanka (Anna) Vsevolodovna, Maria Shvarnovna, Prince Vsevolod Yurievich of Vladimir, St. Euphrosene of Polotsk, Anna Dalassene

УДК 94(47) ББК 63.3(2)4 DOI 10.25986/IRI.2019.75.1.003

К. В. Вершинин (versh-kv@yandex.ru), М. Ю. Андрейчева (anuta.andr@gmail.com)

ИРИ РАН, Москва,

\section{ДРЕВНЕРУССКИЙ ЭТНОГЕНЕАЛОГИЧЕСКИЙ ТРАКТАТ (ЧАСТЬ 1)}

Статья вводит в научный оборот ранее не исследованный памятник древнерусской книжности - анонимный текст, который предлагается, исходя из содержания, называть этногенеалогическим трактатом. Памятник известен авторам по Великим Минеям Четьим митрополита Макария, еше двум спискам XVII в. и двум отрывкам начала XV и XVII в. Основу текста составляет толкование на Пс 82, перекликающееся с содержанием статьи 6604 (1096) г. Повести временных лет. В первой части статьи представлено издание памятника и археографический комментарий. Сделан вывод, что полные списки трактата включают позднейшие добавления. Реконструирован первоначальный вид памятника. Подробное исследование текста предполагается во второй части статьи.

Ключевые слова: этногенеалогия, Повесть временных лет, Псалом 82, Великие Минеи Четьи, древнерусская книжность

В августовском томе Великих Миней Четьих, под 31 числом, читается весьма любопытный анонимный текст, посвященный «происхождению различных народов от Авраама и Лота»[Иосиф, с. 466]. В соответствии с содержанием мы будем называть его этногенеалогическим трактатом (далее - ЭТ). Будучи отмечен в описании архимандрита Иосифа, ЭТ до сих пор не становился объектом спеџиального исследования. Ниже мы будем, в отличие от Иосифа (описавшего Успенский список ВМЧ), пользоваться томом из Софийского комплекта РГАДА. Ф. 201. Рукописное собрание М. А. Оболенского. Оп. 1. № 161 (далее - О). Фрагмент того же текста, как оказалось, проџитировал А. А. Џеханович по сборнику отрывков XVII в. РНБ. Собр. М. П. Погодина. № 1560 (далее - П; см.: [Џеханович, с. 30]), но без каких-либо археографических комментариев ${ }^{1}$. Дополнительные разыскания выявили еше один список XVII в. - в сборнике РГБ. Ф. 310. Собр. В. М. Ундольского. № 626 $\left(\text { далее }-Y_{H}\right)^{2}$, а также два отрывка - при азбуковнике XVII в. ГИМ. Собр. А. С. Уварова. № 25 ( $\left.4^{\circ}\right)$ (далее $\left.У_{B}\right)$ и в книге «Кааф» 1414/1415 г. ГИМ. Музейское собр. № 4034 (далее $-M$ ), архаический состав которой сам по себе свидетельствует о древности найденного текста ${ }^{3}$. ЭТ содержит параллели с русскими памятниками XII-XIII в., позволяюшие с большой вероятностью признать и его сочинением домонгольской эпохи.

Основу ЭТ составляет толкование на Пс 82, что перекликается с содержанием Повести временных лет, а

\footnotetext{
1 На примере этого источника исследователь продемонстрировал, что Галатию в Средневековье нередко путали с другими географическими областями.

$2 \mathrm{~B}$ списках $O$ и П текст помешен среди антилатинских статей (общими для рукописей являются трактат Никиты С тифата «Об опресноках» и «Написание на латину» киевского митрополита Никифора); в списке $У_{H}$ - после не учтенного в литературе списка «Пророчества Соломона» (о памятнике см.: [Водолазкин, с. 293-311]).

${ }^{3}$ О книге «Кааф» см.: [Турилов, 2012а].
} 
именно со статьей 6604 (1096) г., неоднократно привлекавшей внимание ученых ([Ведюшкина; Дорошенко; Лаушкин] и др.). Первая часть настояшей статьи содержит издание текста с кратким комментарием; во второй части предполагается дать подробное исследование.

Все списки, включая отрывочные, восходят к одному протографу, что видно хотя бы из общей ошибки в самом

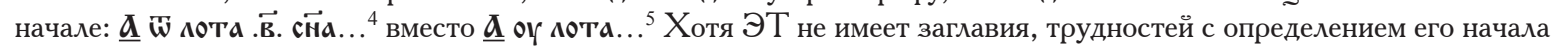
не возникает: во всех рукописях текст начинается с одного места. Однако этого нельзя сказать об окончании ЭТ.

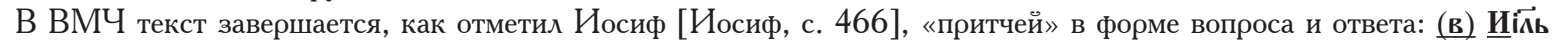

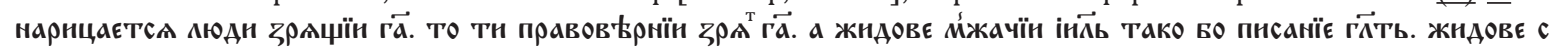

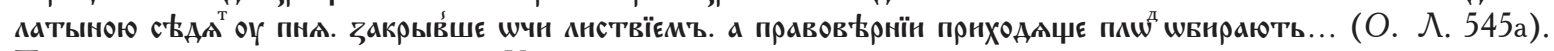
Та же притча имелась в протографе $У_{H}$; в самой этой рукописи от нее осталась лишь начальная фраза, оборванная на слове тако. В П притча не только читается в полном объеме, но и продолжена рассуждением о «душевней Џеркви» и «духовнем крине». Это рассуждение дословно заимствовано из анонимного толкования на ирмос 3-й песни 2-го гласа («Проџвела есть пустыни, яко крин...»), известного, в частности, списку в сборнике: РГАДА. ФФ. 181. Рукописный отдел библиотеки Московского Главного архива Министерства иностранных дел. Оп. 5 . № 478 (далее - МГАМИД 478), XVI в. (入. 509-510 об.)

По-видимому, связь притчи с основной частью текста - чисто механическая, и ЭТ не дошел до нас в первоначальном виде, «обрастя» на каком-то этапе рукописной традиџии инородными «џентонными» Фрагментами. Подтверждает это анализ состава текста в ВМЧ. Здесь перед ЭТ помешена статья «О власех» (О. ᄉ. 544в; в других списках ЭТ, перечисленных выше, она отсутствует). Эта статья представляет собой 28-й вопросоответ Феодорита Кирского (посвящен запрету стричь голову и бороду из Лев 19: 27-28) в особой редакџии, описанной и изданной В. М. Истриным по сборнику XVI в. ГИМ. Синодальное собр. № 682 [Истрин, с. 78]. В ВМЧ он помешен по тематической аналогии с ближайшими статьями, так как содержит антилатинскую инвективу: то како

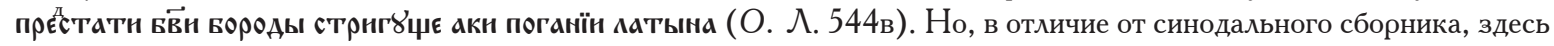

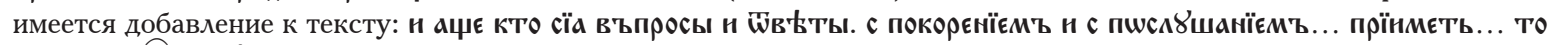
велнц' МАТТ БЖї̈ сподоБАтсА (!)... (О. А. 544в).

Единственный вопросоответ, читающийся в ВМЧ в составе ЭТ, - это притча о «пне» и сидящих у него «жидовех» и «латине». Однако в сборнике конџа XV - начала XVI в. РГБ. Ф. 304/I. Главное собрание библиотеки Троиџе-Сергиевой лавры. № 768 (далее - Тр. 768) отыскивается џелый комплекс вопросов и ответов на избранные стихи Писания (Л. 302 об.-304 об.); сами эти тексты находят аналогии в древнерусских толковых сборниках ${ }^{7}$, но в троиџкой рукописи после них читается упомянутая притча, а затем вопрос Феодорита с проџитированной выше концовкой (ᄉ. 304 об.-305). Таким образом, становится понятно, какие «вопросы и ответы» в этой конџовке имеются в виду.

Далее в троиџкой рукописи под заглавием w плАсанйн читается (с незначительными разночтениями) весь текст,

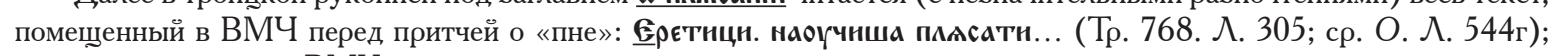
разниџа в том, что в ВМЧ окончание фрагмента о «еретиках» переставлено в начало притчи о «пне» с помоџью явно искусственной связки: тако во пнсанїє г्रтть (О. А. $545 \mathrm{a})$ :

ЖНАОВе с МАТнНОЮ сњАA

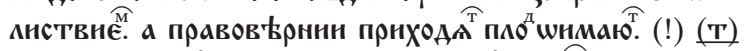

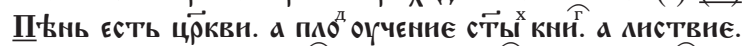
огченне днгаволе. вста гр $<\ldots>$

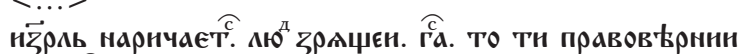

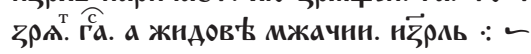

(Тр. 768. ᄉ. 304 об., 305 об.)

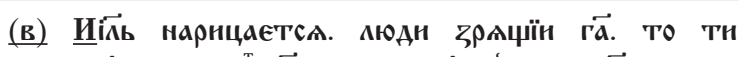

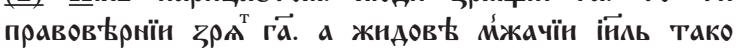

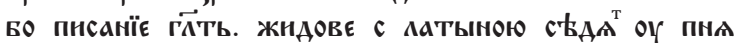

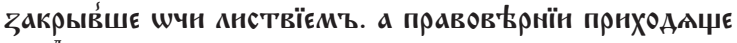
паш" швнрають.

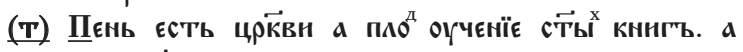

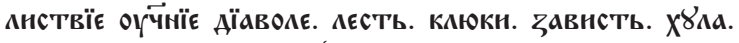

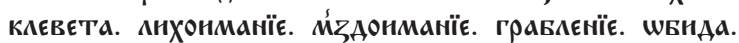

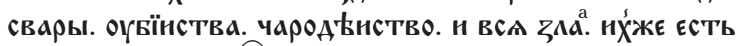

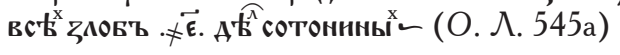

Вторичность текста ВМЧ понятна не только из того, что «Писание» ничего подобного не «глаголет», но и из толкования притчи, текст которого начинается сразу с образа «пня» и не имеет прямой связи с противопоставлением

\footnotetext{
4 Здесь и далее при џитировании подчеркиванием обозначены киноварные написания.

В П можно отметить случай џоканья - цицы (Л. 37) (если только это не описка под влиянием второй буквы ц), свидетельствуюший, возможно, о том, что рукопись, как и Софийский список ВМЧ, имеет новгородское происхождение.

6 Текст не издан. Начало: Пొрьвоє оүво начн४ кацати пнсає внднмын крннъ... ( ( . 509). Судя по деклараџии автора, что он нє оүчнв́сл фннософїн ( $(.510$ об.), происхождение памятника связано с Русью: отриџание «афинейской премудрости», иногда без прямого упоминания Афин, - известный топос русской книжности [Буланин, с. 224-248]. А. А. Турилов оценивает упомянутую рукопись РГАДА как «коллекџию древнерусских литературных раритетов» [Турилов, 20126, с. 297]. Другие списки (XVII в.): РГБ. Прян. 89 (Л.239 об.), РГБ Гуслиџ. 93 (Л. 174).

7 Рамки данной статьи не позволяют расписать эти вопросоответы, но нелишне указать, что почти все они читаются в разделе

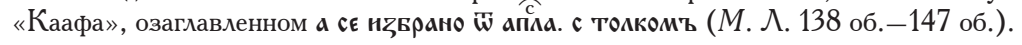


«зрячего» и «незрячего» Израиля. Кроме того, редактор расширил перечень грехов, составляющих «учение диаволе» 8

Что касается фрагмента о «еретиках», то и он «кочевал» по сборникам и обнаруживает инородное по отношению к основному тексту происхождение. Он делится на две части: о «плясании» и о еретических книгах. Вторая часть нигде не находит параллелей, но первая в более полном виде встречается в толковой компиляџии XII - начала XIII в., известной по рукописям МГАМИД 478, XVI в. (Л. 380 об.-381) и БАН. 45.11.16, конџа XV в. ( ᄉ. 146-146 об. $)^{9}$. Если в дополнении к ЭТ и в сборнике Тр. 768 рассказано только о стремлении «плясать» неких «еретиков», буквально истолковавших слова о радости џаря Давида перед Ковчегом ${ }^{10}$, то здесь мы узнаем, что на основании прямолинейного понимания Писания отступники также учили «лихву взимати» и «плескати рукама» ${ }^{11}$.

Никаких следов толкования на Пс 82 в Тр. 768 нет. Позволительно поэтому думать, что первоначально ЭТ состоял из одного этого толкования и завершался родословием «сынов Лотовых» непосредственно перед вставкой о «еретиках» (см. ниже). Между тем едва ли џелесообразно препарировать текст, отсекая позднейшие дополнения (кроме того, перечень «еретических» книг, к которым подобраны сочинители из числа «поганых» народов, представляет значительный интерес), так что ниже ЭТ издается в дошедшем до нас пространном виде.

Следует отметить, что в списке $П$ самое начало ЭТ разорвано вставкой неизвестного происхождения: моглъ

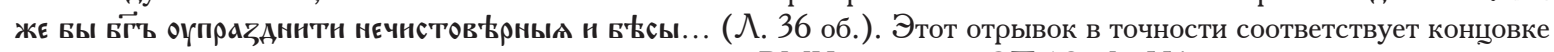
антилатинской статьи а се w опрtсноц中, помешенной в ВМЧ чуть ниже ЭТ (О. ‥ 551a; оставшуюся часть статьи - с начала и до слов могиъ жє - составляют две выдержки: из послания митрополита Никифора Владимиру Мономаху о вере латинской ${ }^{12}$ и из приписываемого Феодосию Печерскому послания князю Изяславу на ту же тему $^{13}$ ). Вероятно, в протографе $П$ также читалась антилатинская статья, но там (в отличие от О) фрагмент, начинаюџйся словами моглъ жє, был отмечен киноварным иниџиалом, из-за чего писеџ сборника обратил на него внимание и выделил из текста.

$* * *$

Ниже текст ӘТ публикуется по старшему полному списку: РГАДА. ФО. 201. Рукописное собрание М. А. Оболенского. Оп. 1. № 161. Ок. 1538 г. ᄉ. 544в-545а. Текст списка передается с сохранением орфографии и пунктуаџии рукописи, с делением на слова, без сохранения построчного деления. 入игатуры раскрываются. Знаки ударения и придыхания не воспроизводятся; киноварные написания отмечены подчеркиванием. Разночтения (кроме орфографических) указываются по рукописям:

РГБ. Собр. В. М. Ундольского. № $626\left(У_{H}\right)$. XVII в. ᄉ. 86-89;

РНБ. Собр. М. П. Погодина. № 1560 (П). XVII в. ᄉ. 36 об.-37;

ГИМ. Музейское собр. № 4034 (М). 1414/1415 г. ᄉ. 231 об.-232;

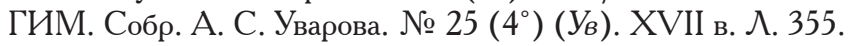

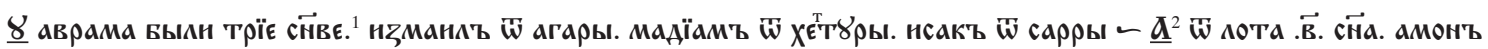

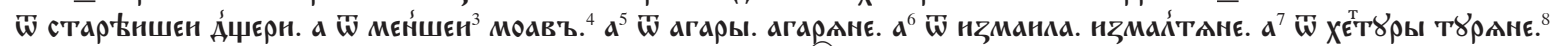

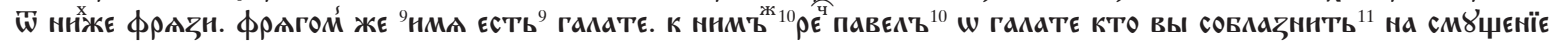

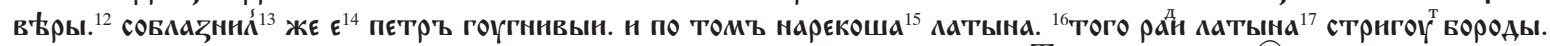

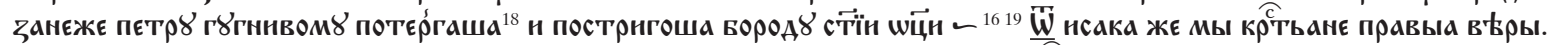

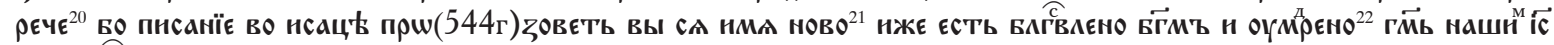

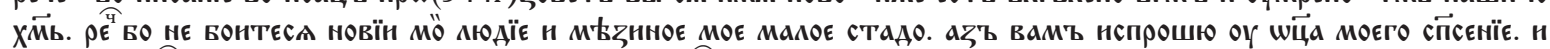

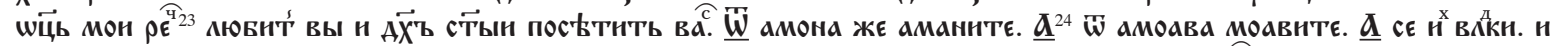

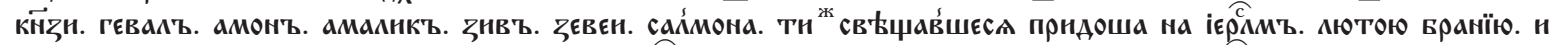

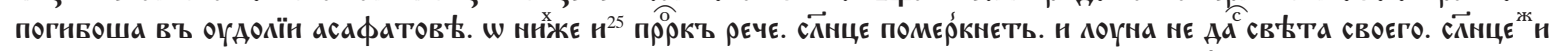

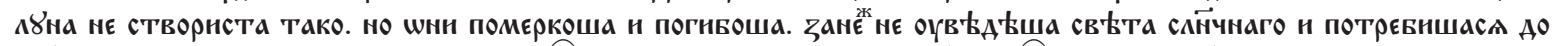

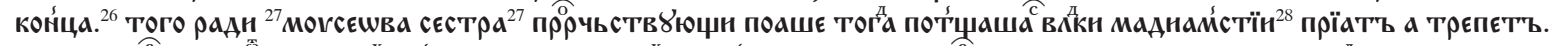

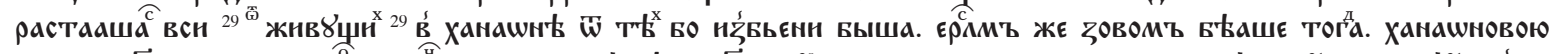

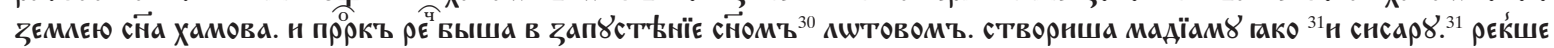

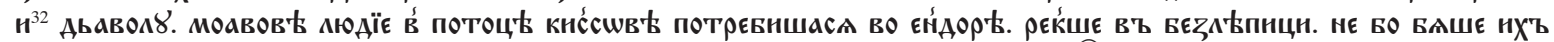

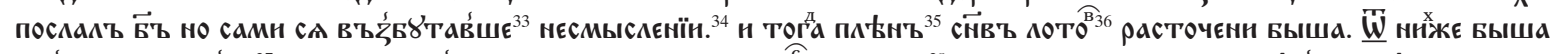

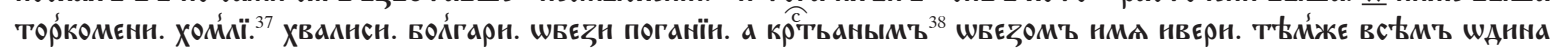

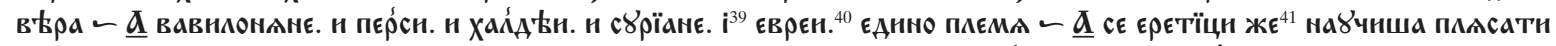
ПаЧЕ ЖЕ АЬАВОЛЪ ЕРЕТИКН НАОГЧН. МЮАН ${ }^{42}$ СОБААЗННТН ВО ВСЕМЪ САЫШАВ́ШЕ

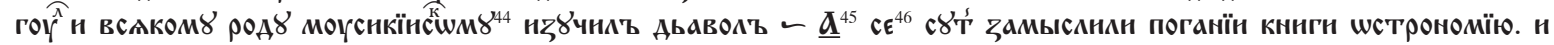

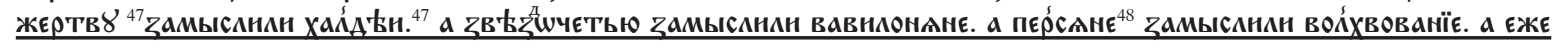
${ }^{8}$ Возможно, не без влияния помешенной в ВМЧ ниже статьи «А се грехи» [Смирнов, с. 45-50].

9 Об этой компиляџии см. подробнее: [Вершинин].

10 «И Мелхола дши Саулова приницаше оконџемъ и виде џаря Давида скачуша и играюша пред Господемъ» (2 Џар 6: 16).

11 Имеются в виду стихи: «Аз взял бых свое с михвою» (Мф 25: 27); «Вси язышы восплешите руками» (Пс 46: 2).

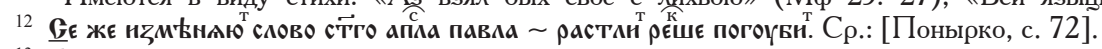

13 Ближе всего к редакџии «b» (однако первая фраза, заимствованная из конџа послания, существенно дополнена: $\frac{d}{\mathrm{~d}} \mathrm{w}$ латын' велнка тАгота писати аце БО Бы и всю земАю попнса станєТе WШ૪юю пАачюџе гор́ко. Ср.: [Бармин, с. 510, 513]). 


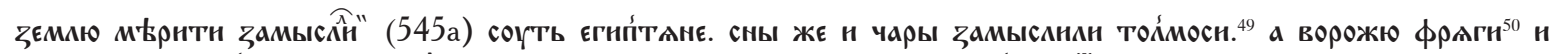

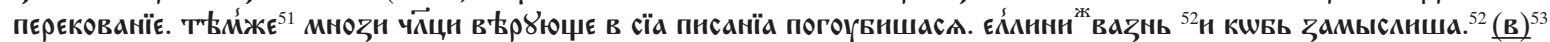

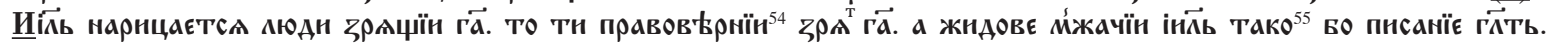

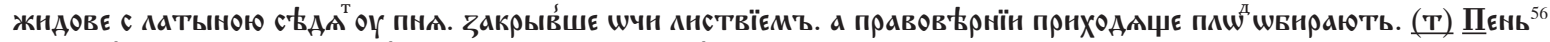

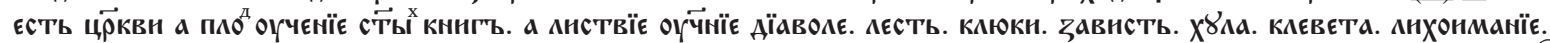

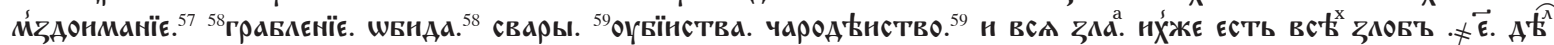
сотонннь ${ }^{\mathrm{x}}{ }^{\circ} \mathrm{c}$

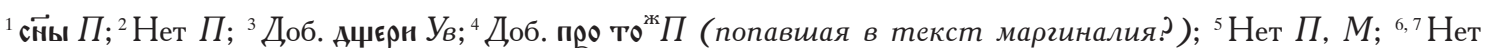

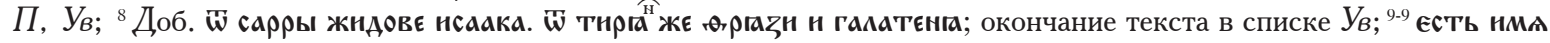

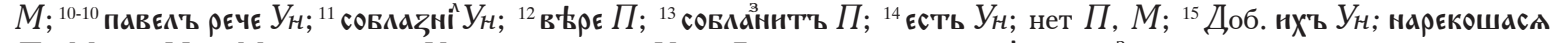

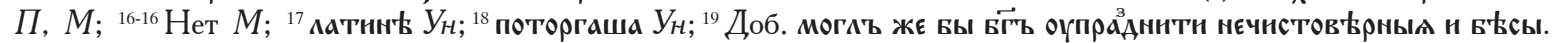

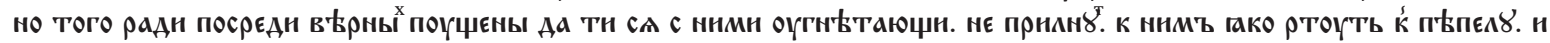

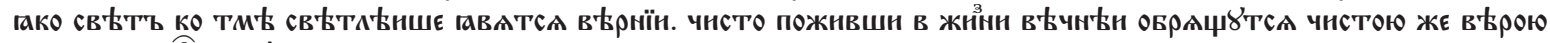

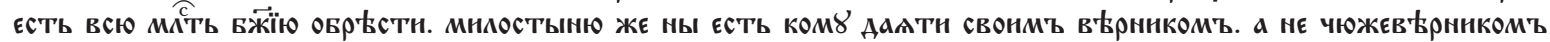

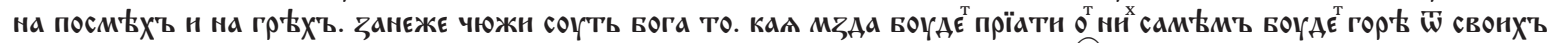

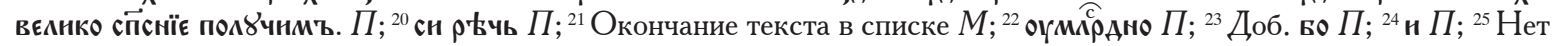

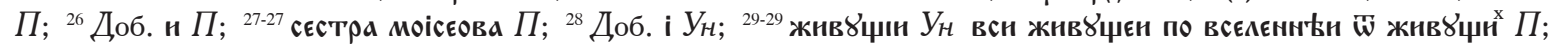

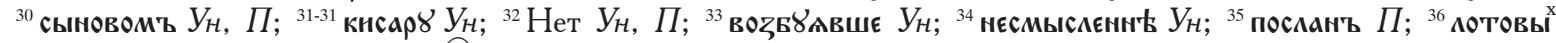

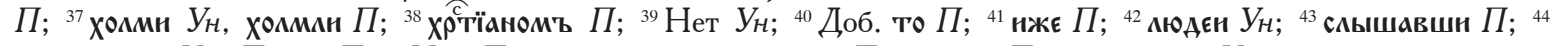
м४снкінскУ $У_{H}, \Pi ;{ }^{45}$ и $\Pi ;{ }^{46}$ Нет $\Pi ;{ }^{47-47}$ Халд по $У_{H}, \Pi ;{ }^{51}$ ть'мъ не $П ;{ }^{52-52}$ zамыскнша и кобь $П ;{ }^{53} \mathrm{~B}$ ркп. написано на поле; нет $У_{H}, \Pi ;{ }^{54}$ Доб. чйцы П; ${ }^{55}$

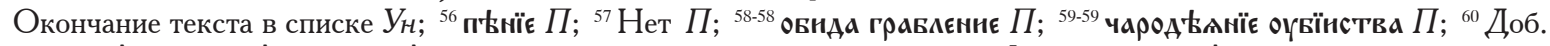

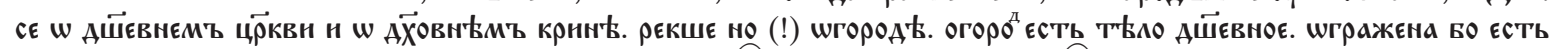
Т"БАомъ Аш̈а. Аш̈

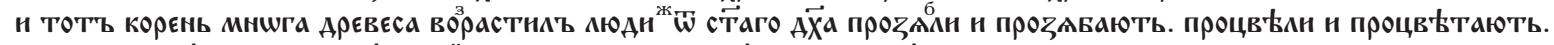

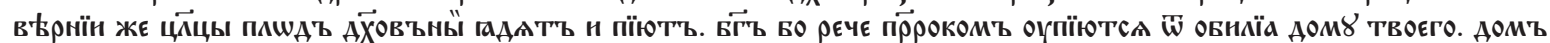

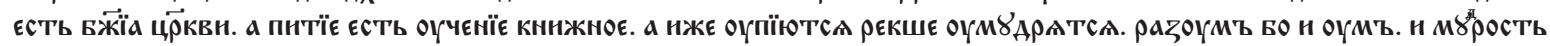

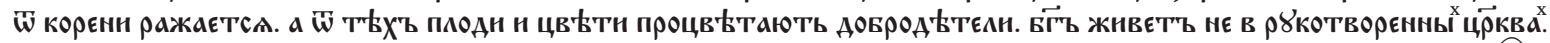

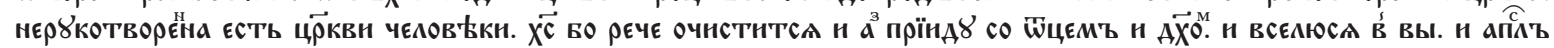

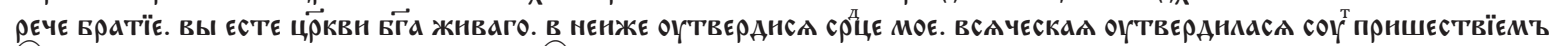

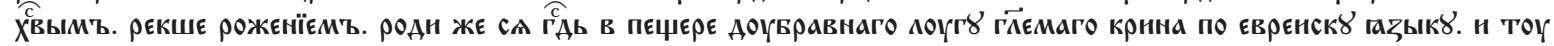

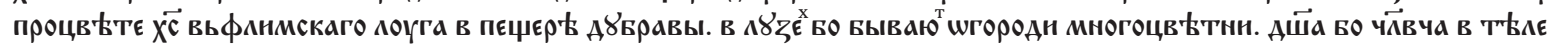

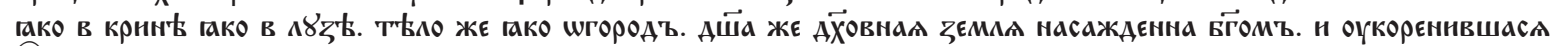

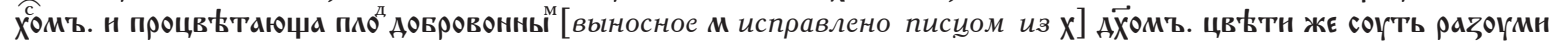

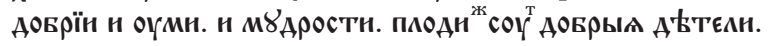

Бармин А. В. Полемика и схизма. М., 2008.

\section{Литература}

Буланин Д. М. Античные традиџии в древнерусской литературе XI-XVI вв. Mbnchen, 1991.

Ведюшкина И. В. Этногенеалогии в Повести временных лет // Древнейшие государства Восточной Европы: Материалы и исследования: 2002 год: Генеалогия как форма исторической памяти. М., 2004. С. 56-60.

Вершинин К. В. Об одном источнике Мерила Праведного и Кормчей // Древняя Русь. Вопросы медиевистики. 2017. № 1 (67). С. 5-8.

Водолазкин Е. Г. Всемирная история в литературе Древней Руси (на материале хронографического и палейного повествования XI-XV веков). 2-е изд. СПб., 2008.

Дорошенко М. Ю. Ветхозаветная топонимика в статье 6604 г. Повести временных лет // Диалог со временем. Альманах интеллектуальной истории. 2007. № 18. С. 370-382.

Иосиф, архим. Подробное оглавление Великих Четиих Миней всероссийского митрополита Макария. М., 1892.

Истрин В. М. Замечания о составе Толковой Палеи. СПб., 1897. Вып. 1.

Лаушкин A. В. Наследники праотџа Измаила и библейская мозаика в летописных известиях о половџах // Древняя Русь. Вопросы медиевистики. 2013. № 4 (54). С. 76-86.

Понырко Н. В. Эпистолярное наследие Древней Руси XI-XIII вв. СПб., 1992.

Смирнов С. И. Материалы для истории древнерусской покаянной дисџиплины. М., 1912.

Турилов А. А. Кааф // Православная энџиклопедия. М., 2012. Т. 29. С. 15. [Турилов, 2012а]

Турилов A. A. «Поучение Моисея» и сборник игумена Спиридона // Турилов А. А. Межславянские культурные связи эпохи Средневековья и источниковедение истории и культуры славян. Этюды и характеристики. М., 2012. С. 286-304. [Турилов, 2012б]

Цеханович $A$. A. Сочинения князя Курбского и полемические антикатолические традиџии древнерусской письменности. К проблеме изучения источников // ВИД. СПб., 2000. Т. 27. С. 19-31. 


\author{
Konstantin V. Vershinin, Marianna Yu. Andreycheva \\ Institute of Russian History of the Russian Academy of Sciences, Moscow, Russia
}

\title{
OLD RUSSIAN ETHNOGENEALOGICAL TREATISE (PART 1)
}

The paper introduces a hitherto uninvestigated piece of Old Russian literacy - a nameless text. Given its content, it is proposed to qualify it as an ethnogenealogical treatise. The authors know the piece from Metropolitan Macarius' Great Menaion Reader, two more copies of the $17^{\text {th }}$ century and two fragments of the early $15^{\text {th }}$ and $17^{\text {th }}$ centuries. The basis of the text is a commentary on Psalm 82 aligned with the contents of the entry for the year 6604 (1096) of the Primary Chronicle. The forepart of the paper provides an edition of the piece and an archaeographic commentary. It is concluded that the full copies of the treatise contain farther additions. The original shape of the piece is reconstructed. A detailed study is expected in the latter part of the paper.

Keywords: ethnogenealogy, $\rho_{\text {rimary }}$ Chronicle, $\rho_{\text {salm }}$ 82, Great Menaion Reader, Old Russian literacy

\author{
УДК 94(47).043 ББК 63.3(2)44 DOI 10.25986/IRI.2019.75.1.004 \\ Чарльз Дж. Гальперин chalperi@indiana.edu \\ Институт России и Восточной Европь Университета Индианы, США. chalperi@indiana.edu
}

\section{ХАН И ЭЛИТА: МОСКОВСКОЕ ВОСПРИЯТИЕ ПОЛИТИЧЕСКОЙ КУЛЬТУРЫ КРЫМСКОГО ХАНСТВА В ПЕРИОД ПРАВЛЕНИЯ ИВАНА IV}

Михаил Хоп предположил, что в рамках политической культуры Монгольской империи и ее преемников было две традиџии: безграничная власть правителя, такого как Чингисхан, и коллегиальная консенсуальная власть - курултай. Согласно московским посольским книгам (Крымским делам) времени правления Ивана IV, московский двор воспринимал политическую культуру Крымского ханства, преемника Улуса Джучи, как сообразную второй парадигме - консенсуального коллегиального государства. Ключевые слова: Иван IV, Москва, Крымское ханство, элита, политическая культура, консенсуальный, коллегиальный

Дискуссия о татарском влиянии на политическую структуру России меняет направление при смене интерпретаџии природы монгольской политической культуры. Во времена «холодной войны» Монгольская империя и ее преемники считались примерами восточного деспотизма, поэтому утверждалось, что Улус Джучи (Золотая Орда) превратила Россию в восточный деспотизм [Wittfogel]. Когда историки, спеџиализируюшиеся на внутренней Азии, стали подчеркивать коллегиальные и консенсуальные элементы Монгольской империи, некоторые спеџиалисты по Московской Руси стали интерпретировать такие черты московской политической культуры, как Дума и Земский собор, как продукты татарского влияния [Ostrowski, 1990; Ostrowski, 1998, р. 1-132; Ostrowski, 2002; Ostrowski, 2004]. Теперь М. Хоп сделал убедительное предположение, что монгольская политическая культура содержала две политические традиџии: одна - фактически безграничной монархической власти, олиџетворяемая в первую очередь властью самого Чингисхана, вторая - консенсуального коллегиального правления, институџионализированная, среди прочего, в проведении курултаев для решения политических и военных задач [Норе]. Поэтому Москва могла унаследовать или заимствовать от татар и авторитарную и консенсуальную модели политической культуры.

Источники времени правления Ивана IV предоставляют значимые свидетельства того, как московская политическая элита воспринимала политическую культуру Крымского ханства - «внука» мировой Монгольской империи. Крымские дела из посольских книг дают детальную информаџию об отношениях Московии с Крымским ханством. Две недавно опубликованные книги предоставили историкам доступ к богатым архивным свидетельствам ${ }^{1}$. В Посольском приказе составили последовательный дипломатический нарратив из исходных материалов записок, инструкџй, посланий и отчетов своих чиновников ${ }^{2}$. Московско-крымские дипломатические контакты были особенно интенсивными между 1567 и 1577 г., включая оттоманско-крымскую попытку завоевать Астрахань в 1569 г., сожжение крымчанами Москвы в 1571 г. и битву при Молодях в 1572 г.

Московские переводчики не имели сложностей при взаимодействии с оттоманизированным крымским тюркским языком дипломатической корреспонденџии из Крыма в Москву, хотя переписчики порой путали тюркские имена [Малов, с. 20].

Московская элита владела обширными знаниями о политической ситуаџии в Крыму. Московия зналаперсонально всех политических игроков Крымского ханства. Иван IV и иногда царевич Иван переписывались с большинством из них. Входящие и исходяшие грамоты были сохранены в государственном архиве, хотя, очевидно, переписку с второстепенными членами элиты не включили в посольские книги [Виноградов, 2015, с. 33]. Корреспонденџией обменивались не только с ханом (џарем) Девлет-Гиреем, но и с его офиџиальным наследником - калгой, царевичем

1 Посольская книга по связям Московского государства с Крымом 1571-1577 гг. / Отв. ред. И. В. Зайџев; подгот. текста А. В. Малов, О. С. Смирнова, Г. А. Тарасова; статьи, комментарии А. В. Виноградов, И. В. Зайџев, О. С. Смирнова, В. Н. Сокуров; приложения А. М. Галенко, И. А. Мустакимов (далее - ПК 1571-1577). М., 2015; Посольская книга по связям Московского государства с Крымом 1567-1572 / Отв. ред. М. В. Моисеев; подгот. текста А. В. Малов, О. С. Смирнова; статьи, комментарии А. В. Виноградов, И. В. Зайџев, А. В. Малов, М. В. Моисеев (далее - ПК 1567-1572). М., 2016. Эти выпуски перекрываются хронологически [Малов, с. 4].

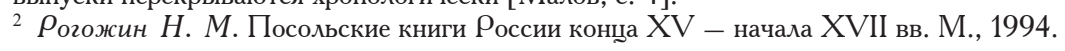

